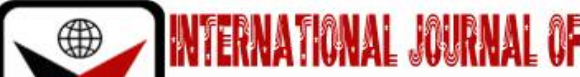

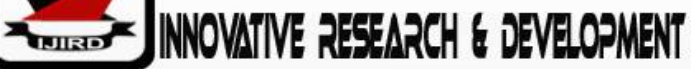

ISSN 2278-0211 (Online)

\section{Content and Investigative Analysis of In-House Journals: A Case Study of National Centre for Agricultural Mechanization (NCAM) Library}

Uzokwe Chuka Christian
Librarian, National Centre for Agricultural Mechanization (NCAM) Library, Nigeria
Oyeniyi Janet Oluwakemi
Olaifa Taye Paul
Deputy Director, National Centre for Agricultural Mechanization (NCAM) Library, Nigeria
Alu Fredrick
Information Officer, National Centre for Agricultural Mechanization (NCAM) Library, Nigeria
Program Analyst, National Centre for Agricultural Mechanization (NCAM) Library, Nigeria
Oyewopo Adewale Oyekunle
Librarian, Nigeria Stored Product and Research Institute (NSPRI) Ilorin, Nigeria

\begin{abstract}
:
Journals are one of the essential information sources that forms the basis for research. Most research organizations publish or float their own journal in other to aid research development in their respective institution; this is called InHouse Journals. This research work seeks to investigate the content analysis of in-house journals using the National Centre for Agricultural Mechanization (NCAM) as a case study. The findings in the research reaffirm the importance of in-house journals. However, it was observed that many institutions cannot maintain their in-house journals because of challenges such as poor funding, poor awareness and un-encouraging attitude towards research in the country. The research concluded by proffering possible solutions towards resuscitating and sustenance of in-house journals in an institution.
\end{abstract}

Keywords: In-house journals, NCAM, agriculture, mechanization, research, library

\section{Introduction}

An in- house journal is a medium of communication that projects the image of a company or an organization or outside, with the purpose of improving employee morale. According to English oxford Dictionary, in-house journal is a publication produced by a particular firm, institution, or society and dealing mainly with its own activities. It could be a newspaper produced by a company to tell employees what is happening in the company or organization. In-house journals have been given a variety of names, such as newsletters, employee newspapers and company newspapers, but, in effect, they carry out the same function. In-house journals are private publications and therefore discussed separately from the commercial press. There are also two distinct kinds of house journals: internals for staff and externals for outside publics. The two are distinct and should not be expected to serve the dual purpose of serving, for example, employees and customers. In-house publications are not confined to the world of commerce and industry, even if in-house journal editors have, in the past, been given the curious title of " industrial editors". In-fact, private magazines and newspapers are published by almost every kind of organization, whether it is in the public or private sector, commercial or not-for-profit. Although some of these previously printed publications have converted in whole or part to electronic media, it is not so much the medium but the message that is important, and which medium best suits the function of reaching the target public. The sales bulletin is a regular communication, perhaps weekly, between a sales manager and sales representative in the field.

In house journal can also be seen as publications produce by a particular firm, institution, or society and dealing mainly with its own activities. Early scholarly articles also refer in-house journals as "house organs" and define them as small magazine or newspaper published once in a month, sometimes more frequently, sometimes less and made up wholly or in part of advertising from the house sending it. An in-house journal is a publication published by corporate, public sector undertakings, organizations, associations, institutions, and government departments in order to highlight their products, achievements, accomplishments, events, perceptions, and future endeavours. In-house Journals are not meant for sale and hence they do not have a price tag. Although most in-house Journals are meant for the internal public, some of 
them are distributed among the external public who are related with identical work/industry/sector, catering to the similar type of work or products. (Ask Opinion 2018).

\subsection{Contextualisation: The History of In-House Journals}

According to Wood (2006) the first journal in the United States (US) that was aimed at employees was published in 1846 and was called the NCR Factory News. Much later, during World War I, companies became more aware of the fact that the needed to communicate with their employees. The industrial era following the war brought about new in-house journals mainly to inform them in general about what was happening in the company.

By 1921 there were about 334 in-house journals in the US, of which 91\% started between 1917 and 1920 . At the beginning of World War II in 1939, companies not only used in-house Journals to inform their employees on internal company issues, but also on sentiments regarding the war. However, once the war was over and the world was engulfed in the depression, many in-house Journals disappeared, due to lack of funding. Over the years, there was steady increase in the development of in-house Journals and by 1958 US companies spent an estimated US\$ 100-million on in-house Journals. Today, the publication of in-house Journals is a major industry across the world reaching billions of people. With the development of technology, and specifically desktop publishing, it has become even easier for companies - big or small to produce a professional Journal at a reasonable cost.

\subsection{Literature Review}

According to Gupta (2013), in-house journal, also called newsletter or company newspaper is one of the preferred ways of communicating with the employees of an organisation about various activities and developments that are taking place in any sphere of the organisation. Since there is absolute freedom regarding editorial style of the in-house journal, which can be modulated according to the requirement of the audience; moreover, it enjoys the authenticity of formal channel of communication and tone of informal channel of communication. The in-house journal creates a smooth multidimensional channel of communication in organisation.

Pompously speaking it is a drum of beating for companies but on a moderate line, it serves as a bridge between the management and staff or between two companies, to showcase the objective and work done by them, their projects in the pipeline, and what social cause or purpose it is serving, in addition to its normal day-to-day business. It also helps the staff or employees to get united wherever they are. Institutions or organizations who feel the necessity of House Journals and are affluent enough to afford such journals allocate hefty sums for their publication in their annual budget.

The method of publication of in-house Journals is also very simple, either there is a separate cell within the organization, comprising of professions mostly from the field of print media/public relation s or any professional publication house, advertising agency, or public relation firm is hired to run the publication on a contractual basis. Employees who have exceptionally phenomenal writing skills also contribute to House Journals. Other sources of news materials can also be the market review of products, books related to the subject of the products, their background, and laws and norms that apply to that particular sector. Editing in such journals need not to be as fussy or flawless as in newspapers or magazines. The aim or objective of such journals is to publicize or display the work of companies in a liberal or light-hearted manner. (Ask Opinion 2018)

Gupta (2013) said that, in-house Journal can be best used to explain safety issues in manufacturing concerns. It is much easier to explain safety protocols, safety methods of working to factory workers in language most suited to their need through house journal than any other mode of communication. The strategies and vision developed at senior management are often distorted as they pass each channel and lower level employees often do not get right message resulting in resistance to new strategies, plans, etc. Employee in-house journal explain the evolving nature of philosophies, strategies future plans, their implications directly to the employees thus reducing distortion and resultant resistance.

Wood (2006) argued that an excellent in-house journal is evaluated regularly and necessary changes are made to ensure it continues to serve its purpose. An in-house journal is the most versatile, adaptable and, in the long run, the most costeffective medium for internal communication. It provides information for reference purposes, can be read in employee spare time and also includes their families. It is important though to remember that in-house journals are not only form of communication, but compliment other ways of communication, Ferreira \& Staude (1991).

An added advantage of in-house journals, writes Hunt and Mckie (2000) is that they have greater potential than many other communication tools (memos and leaflets) for a two-way relationship with readers: readers can, inter alia, be invited to contribute letters to the editor, enter competitions and provide suggestions for articles. Wilcox and Nolte (1995) describes the sponsored periodical (company newsletter, newspaper or magazine) as a major tool of internal communication. They state that such publications are effective channels of continually supplying information about the employee.

Argenti (2000) agrees that while, meetings are an important way to communicate with employees, the most common form of interaction on a regular basis bound to be through the print medium. Although the electronic media (for example e-mail and companies own internets) are widely used in the corporate world to communicate with employees, all the editors interviewed on this agree that the print medium is still preferred as official communication medium. According to the editors, employees feel that because issues are discussed in print (and therefore be read by anyone and referred back to) the printed information provided on these issues is credible (Dower, 2005; Paige, 2005; Redelinghuys, 2005).

Therefore, in-house journals offer an effective means of communicating with employees. To achieve this, however, an inhouse journal should not be collection of trivia but should contain items of interest regarding the company and its employees (Newsom, Scott \& Vanslyke Turk, 1992) 
Wilcox \& Nolte (1995) also argued that, for a communicator to produce a relevant and interesting in-house journal, he/she must convince management that it is in the best interest of the company to permit open, candid communication. The credibility of the in-house journal as communication channel to disseminate information will depend on the successful integration of two endeavours that are usually not compatible, the accomplishment of company goals and the satisfaction of employee needs. It is therefore important to keep the following in mind:

- Communication policies must be understood by management

- These communication policies must be clearly explained to the team of employed in the enterprise. Here the inhouse journal has an important place among many skills and techniques of effective communication.

- An in-house journal editor must be at the heart of communications network.

- The responsibility for an in-house journal lies with senior management

- A journal must encourage two-way communication

- The overriding aim of the in-house journal is to inform readers (Skinner \& von esson, 1987)

From this, one can determine that an in-house journal is one internal public relation as tool that can be used to satisfy the need of employees to receive information, allow them to communicate with management and offer management a tool to communicate with employees. The in-house journal is therefore a key element in a company's overall communication strategy Lubbe \& Puth (2002)

\subsection{Statement of the Problem}

\subsubsection{NCAM Library}

The National Centre for Agricultural Mechanization Library is a Research Library that responsible for providing reference literature and other information services in-line with the mandate and objectives of her parent body. The library acquires information (published and unpublished) in General Agriculture, Mechanization, Engineering, Social Sciences, Management and other related fields. The library has various collections ranging from Textbooks, Journals, Magazines, Manuals and many other print and non-print materials. The collections in NCAM Library are classified using in-House classification scheme, which covers areas such as Farm Power and Machinery, Processing and Storage, Land and Water Engineering, General Agriculture, Mechanics, Social Sciences, Post-Harvest Engineering etc

\subsubsection{Objective of the Study}

The main objective of the study is to investigate the non-availability of in-house Journals in NCAM Library. While the specific objective is to:

- Identify the importance of In-House Journals to research

- Identify the challenges facing in-house journal publication.

- Proffer possible solutions to reviving in-house journals

\section{Findings and Discussion}

Figure 1 below reveals the gender distribution of respondents. The figure shows that $81 \%$ of the respondents are male while only 19\% are female. This result corroborates with the submission of Oyeniyi et.al (2014) that there exists a notable gap between male researchers and their female counterpart.

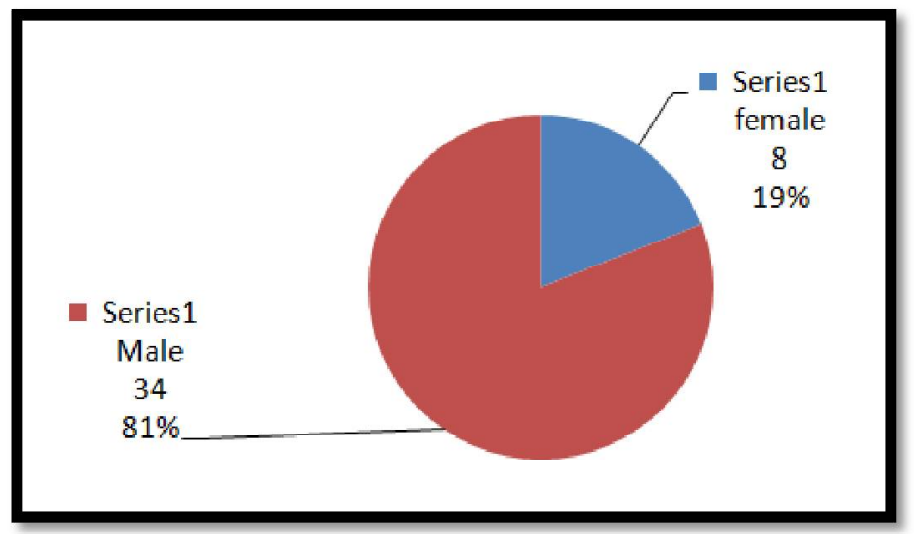

Figure 1: Gender of Respondents 


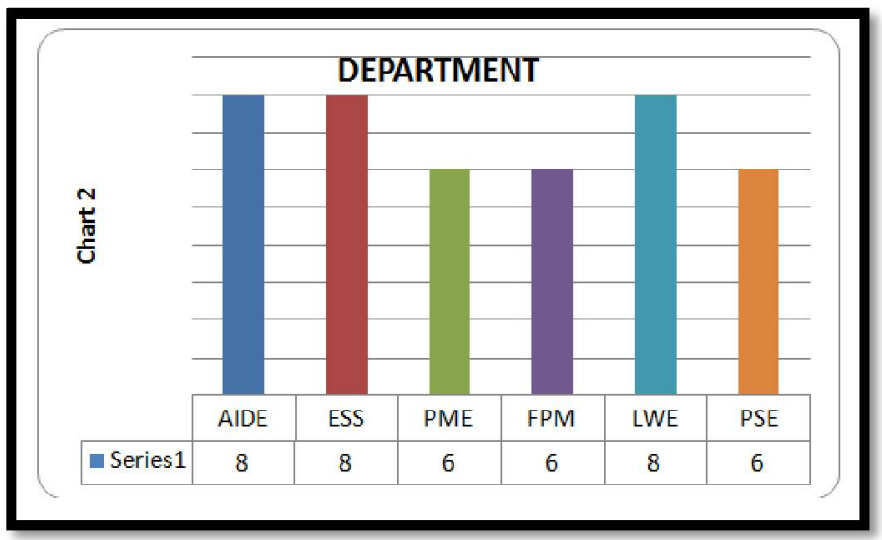

Figure 2

Figure 2: Figure 2 represents the departmental analysis of the author. The figure reveals that the respondents were selected across the research departments in NCAM. A total number of 42 respondents comprising of both male and female researchers were used.

\begin{tabular}{|c|c|}
\hline YES & 41 \\
\hline NO & 1 \\
\hline
\end{tabular}

Table 2: Have you heard about In-House Journals before

Table 2 above answered the question whether the respondents have heard about in-house journals before. The question is necessary so as to ascertain the basis for further questions relating to experiences gathered in the course of using in-house journals. The table revealed that 41 respondents/researchers contacted have heard about in-house journals before, while only 1 respondent has not heard about in-house journals before.

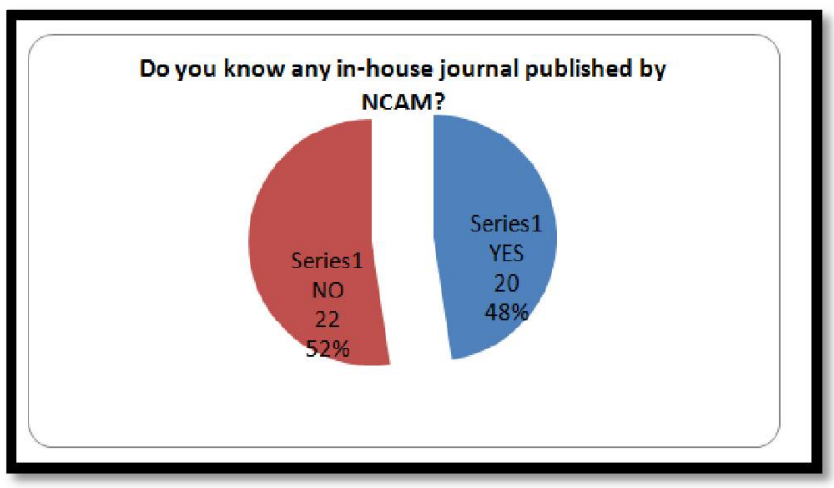

Figure 3

Figure 3: Figure 3 reveals the percentage of the respondents who know and who don't know about any Journal published in NCAM. Through the above figure , $52 \%$ of respondents claimed they had no knowledge of any Journal published by NCAM while $48 \%$ thought otherwise.

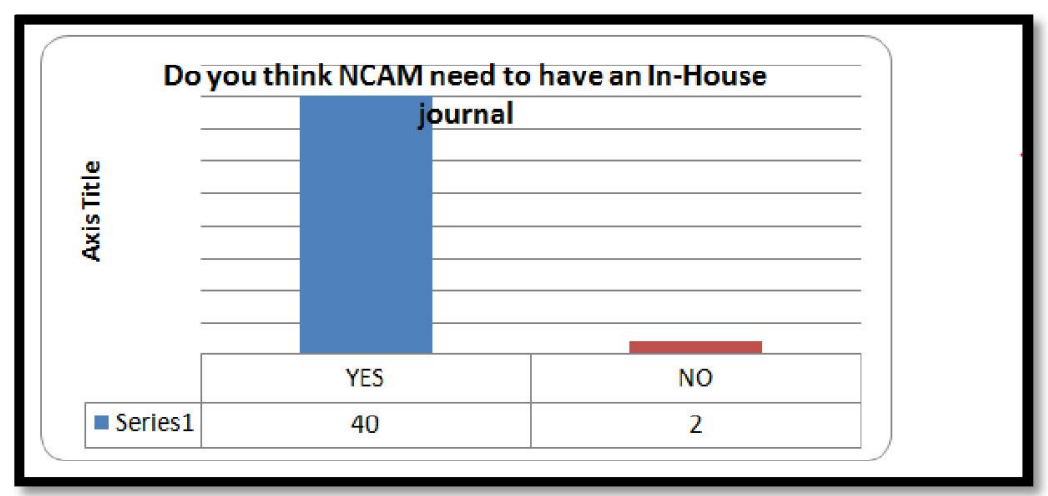

Figure 4

Figure 4: Figure 4 confirms the total number of respondents who believe that NCAM needs an in-house Journal. The figure shows that 40 respondents think NCAM needs an in-house Journal while only 2 respondents disagreed on that. 
This further aligns with GUPTA (2013) that in-house Journal is necessary in an organization because it is one of the preferred ways of communicating with the employees of an organization about various activities and developments that are taking place in any sphere of the organization.

\begin{tabular}{|c|c|}
\hline YES & 41 \\
\hline NO & 1 \\
\hline
\end{tabular}

Table 3: Do You Think Journals Contribute Anything to Research Development

Table 3 above provided answers to the question whether journals contribute to research development or not. 41 respondents accepted that journals have a significant contribution to research development while only 1 respondent opined negatively.

\begin{tabular}{|c|c|}
\hline YES & 39 \\
\hline NO & 3 \\
\hline
\end{tabular}

Table 4: Do You Think the In-House Journals Should Spread to Other Related Institution or Within NCAM Only

The question was asked if it is better to spread in-house journals to other related institutions or not. Table 4 above shows that 39 respondents are of the opinion that in-house journals should not only circulate within an institution but should be spread to other related institutions. 3 respondents however declined to this opinion.

\begin{tabular}{|c|c|}
\hline YES & 42 \\
\hline NO & 0 \\
\hline
\end{tabular}

\section{Table 5: Do You Think Publishing an In-House Journal} Can Help Publicize an Establishment

In table 5 above, all the 42 respondents agreed that publishing an in-house journal is a way of advertising an establishment.

\begin{tabular}{|c|c|}
\hline YES & 6 \\
\hline NO & 36 \\
\hline
\end{tabular}

Table 6: Have You Used Any NCAM In-House Journals Before?

In table 6 above, a question was asked whether the respondents have used any NCAM published journals before. In their response, only 6 respondents have used NCAM published journals before while the majority of the respondents (36) have not used any of NCAM published journals. The result from this table questions the availability and consistency of NCAM in-house journals.

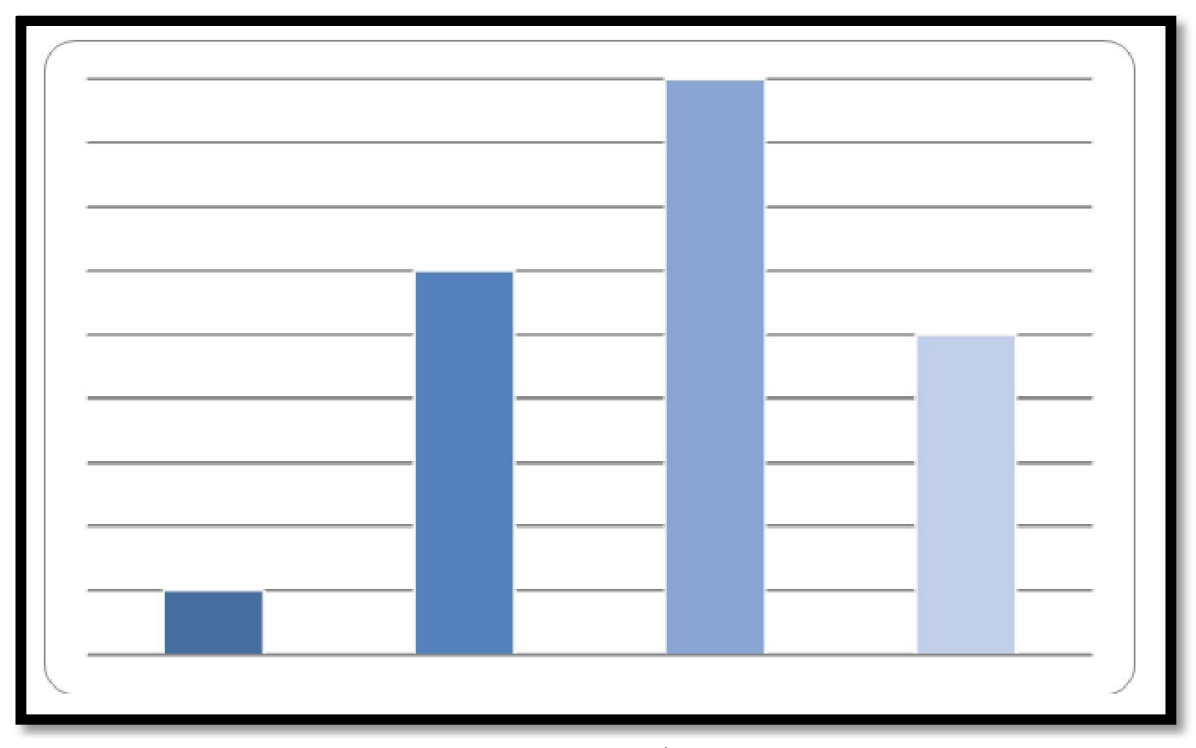

Figure 5

Figure 5: Figure 5 reveals what is thought to be responsible for the non-availability and in-consistency in publishing an in-house Journal by NCAM. The figure revealed that 18 respondents believed that the challenges are due to poor funding. This opinion agrees with E Wood (2006) who noted that many in-house Journals disappeared due to lack of 
funding to be used for publishing. This further proves beyond doubt that funds are very important in all research activities. 12 respondents also pointed at No awareness, 10 claimed all of above while 2 respondents belief research attitudes are responsible for the non-availability and inconsistency of NCAM in-house journals.

\section{Conclusion and Recommendations}

This research paper has been able to establish the importance of in-house journals to research development. In the cause of the research, it has been noted that in-house journals also help in publicising the institution as well as sustaining the educational and research values. In other to revive the publishing of in-house journals in our institutions in Nigeria, the following suggestions are hereby recommended.

Government should ensure adequate funding of the institutions in other to cub the strong poor funding challenges currently faced especially by research institutes across the country.

Institutes should be encouraged and mandated to promote research by floating at least one in-house journal.

There must be concrete collaborations between research institutes and the Universities especially on research. Most universities already have their floated in-house journals, if such journals are published in collaboration with a research institute, it will improve the quality of research for the benefit of the duos.

The institutions that currently publish in-house journals must also ensure the wide spread of the journals in other to create awareness and generate income for the sustainability of the production.

The attitude of the government towards research must also be improved. This can be done by timely and adequate release of research fund, sponsoring of research and researchers, organising symposium, workshop, seminar etc.

\section{References}

i. Argenti, P.A. (1998). Corporate communication. Boston: Irvin/McGraw-Hill

ii. Ask Opinion. (2018) https://askopinion.com/importance of house journals for corporate world

iii. Dower, S. (2005). Publishing consultant for Words Worth. Interview conducted via e-mail. Answers in possession of researcher.

iv. E Wood. (2008). Excellent In-House Journals in South Africa: A case studies of five leading publications. Potchefstroom Campus.

v. Ferreira, T \& Staude I. (1991). Write Angles: the ABC for House Journals. Melville: Write Minds

vi. Hunt, M.L \& Mckie, D. (2000). Public Relations Tactics (Johnson, J \& Zawawi, C. ed. Public Relations- theory and practice. St Leonards, Australia: Allen \& Unwin)

vii. Lubbe, B.A \& Puth, G. (2002). Public Relations in South Africa: a management reader. Pietermaritzburg; Heinemann

viii. $\quad$ Newsom, D; Scott, A \& Vanslyke Turk, J. (1992). This is PR. Belmont: Wadsworth

ix. Oyeniyi, J.O; Olaifa, T.P; Uzokwe, C.C (2014) Authorship of Books and Gender Sensitivity: A Case Study of NCAM Library Collections Journal of Balkan Libraries Union Vol. 2, No. 2, pp. 6-11, 2014.

x. Paige, R. 2005. Editor of Hello the future. Interview conducted on April 14, 2005. Transcript in possession of researcher

xi. Redelinghuys, E. (2005). Editor of Abacus. Interview conducted on April 26 2005- Transcript interview in possession of researcher

xii. Guputa, R. (2013). House Journal: An Effective Mode of employee communication. Thesis submitted to the University of Lucknow for the degree of Doctor of Philosophy in Journalism \& Mass communication.

xiii. Skinner, J.C \& Von Essen, L.M. (1987). South African handbook on public relations. Johannesburg: Macmillan

xiv. Wilcox, D. L, Ault, P.H \& Agee, W.R. (1995). Public Relation: Strategies \& tactics. New York: HarperCollins college publishers 